\title{
INCULTURATION: BLENDING CHRISTIANITY INTO LOCAL CULTURE
}

\author{
Robinson bin Benedict Mugok, \\ Email: robinson.benedict@gmail.com \\ Faculty of Social Science, Universiti Malaysia Sarawak, \\ Kota Samarahan, Malaysia.
}

\section{Elena Chai}

Email: gelena@unimas.my

Faculty of Social Science, Universiti Malaysia Sarawak, Kota Samarahan, Malaysia.

*Corresponding authors

Email address: robinson.benedict@gmail.com

\begin{abstract}
As Christianity seeks to spread its mission around the world, they face cultural barriers in a way that Christianity is not always easily acceptable to the non-European settings due to the differences in values and cultural practices. In order to cope with such challenges, the churches established inculturation and equivalent policies in evangelizing and minister the non-western communities worldwide. In Kampung Bungan Besar, Matu, a Melanau-populated village, Christianity at the present time is the main religion alongside with the minority practitioners of traditional belief. The growing of Christianity from a totally 'foreign' religion to the main religion among the Melanau can be associated with the missionary efforts, and it is the inculturation process that ensured the triumph of the mission. Liturgical inculturation and object-centered inculturation is the most obvious two inculturation strategies used in spreading of the gospel message among the Melanau.
\end{abstract}

Keywords: Christianity, Inculturation, Melanau, Liturgical Inculturation, Object-centered Inculturation. 


\section{INTRODUCTION}

This paper aims to study the inculturation of Roman Catholic missionaries among the Melanau of Kampung Bungan Besar, Matu, Sarawak. Prior to that, before the arrival of Christianity, the Melanau does have their own set of belief system known as adet dana (Dzulfawati Haji Hassan, 2006, p. 32) and the belief in unseen spirit and supernatural forces (Jeniri Amir, 1998). These forces including the ipok and the malevolent spirits of amow 'ghost', genie and duhig. According to Jeniri Amir (1998), this traditional belief system has a strong influence on the daily living of the Melanau as their customs, interactions with nature, disaster and environment are pre-guided by it.

Roman Catholic missionary among the Melanau can be associated with the arrival of Father A. Stotter at Borneo in 1897 following the establishment of a missionary school in Igan. It was then transferred to Dalat, nearby the Oya River (Ismail Abdul Rahman, 2000, pp. 41-42). Informants claimed that Christianity missionaries in Kampung Bungan Besar, Matu, began actively in 1960's, some claimed 1970's. According to Aseng (1998) Roman Catholic missionary among the Melanau rooted from nearby Kampung Sungai Kut, dated to early 1896 and the establishment of a school, convent and church in Dalat by 1918. The missionary is an instant success despite the strong influence of traditional belief in the Melanau daily lives. Spearheaded by education and channeled through school, Christianity is well-accepted among the villagers as the majority of them convert to Christianity and left behind their adat belief. In 1979, Saint Victoria Chapel was opened and remarked another success of Christian missionary within the region.

Despite strong adat belief among the Melanau, Christianity managed to establish their place within the community faith system. On one hand, this success was believed to be contributed by the strict sense and 'rigidness' of old adat belief that drives the villagers to shift their faith towards Christianity ${ }^{1}$. On the other hand, missionary strategies employed in spreading Christianity play crucial roles as it was channeled via health care, education and general native welfare (Ooi, 1991, p. 284). On top of that, it is the 'inculturation' that the most vital factor in determining the success of church missionary globally. The aim of this paper is to study the inculturation process that eases the spread of Christianity into the life of the Melanau in Kampung Bungan Besar, and, secondly, to identify the forms of the inculturation takes place.

\section{Inculturation}

The term 'inculturation' was first coined in 1973 by G. L. Barney, as the manifestation of the spreading of Christian across the world. It reflects that the gospel could "incarnate in different culture" while simultaneously "introduce(ing) peoples, together with their cultures, into her own community" (John Paul, 1990, in Chua, 2010, p. 142). In Encyclical Letter 1985, the term 'inculturation' is a theological term that defined as "the incarnation of the Gospel in autonomous cultures into the life of the Church" (Grenier \& Dauphin, 2009). In a practical manner, 'inculturation' could be understood as:

"....meant that missionaries and other Church had to immerse themselves in cultural milieu of those to whom they are sent .... understanding, appreciating, appreciating, fostering and evangelizing the culture of the environment which they are working, and ... equipping themselves to communicate effectively with it" (John Paul II, 1990, cited in Chua, 2012, pp. 141-142).

Theoretically, 'inculturation' to Angrosino (1994) is seeking to translate Christian values and modes of thought into their local equivalents, while integrating and socializing other aspects of local society within Christian frameworks (in Chua, 2012, p. 142). In the context of spreading Christian missionaries' worldwide, it is vital for the Christian teachings to adapt or assimilate with the local equivalents but in a sense that the "cultural adaptation that not affect the content of Christian message" (Stewart, 1999, in Chua, 2012, p. 141). By other means, the 'inculturation' is the process where the local culture integrated

\footnotetext{
${ }^{1}$ The findings from interviews with the informants during my Bachelor Degree Final Year Project (FYP) The Life of Christian Melanau in Sarawak: A Case Study of Kampung Bungan Besar, Matu 2015 submitted to Universiti Malaysia Sarawak (UNIMAS).
} 
into Christian teaching, and at the same Christian teaching integrated into the framework of local culture and custom, so these two will not contradict to each other.

Together with the process of 'inculturation' is the "liturgical inculturation", "a process of inserting the texts and rites of the liturgy into the framework of the local culture" such that they would "assimilate people's thought, language, value, ritual, symbolic and artistic pattern" (Chupungo, 1992, in Chua, 2012, p. 142). Among the Bidayuh in Sarawak, the 'inculturation' of Christianity into their culture is through object-centered and aesthetic, as various specific models of Bidayuh's features can be seen in Anglican and Catholic practice such as 'gawai hats', clothing, paraphernalia, baskets, gongs, blue-and-white offering bowls, and baruks (Chua, 2012, pp. 142-143). Furthermore, the 'inculturation' of Christianity into local 'gawai practices' can also be seen in the services that marked the two major stages of the rice-planting cycle; gawai nyipa'an (blessing of the new rice crop) and gawai sawa, the post-harvest festival (Chua, 2012, p. 144). In these services, members of the congregation bring rice plants from their farms, often in small rattan baskets, and placed them at the altar by the priests or prayer leaders. In the meantime, old gawai paraphernalia such as beads, leaf-bundles, and blue-and-white offering bowls become regular components of prayer packages sitting comfortably alongside traditional Christian artifacts such as medallions, rosaries, and pictures of Jesus and Mary (Chua, 2012, p. 144).

On the other region of the globe, Molnar (1997) stated that the conversion of Hoga Sara people into Christianity do not move the people to abandon their traditional belief practice and traditions. Conversion into Roman Catholic does not really impact the traditional practices and customs of the Hoga Sara of Flores even with the implementation 'inculturation' after Second Vatican Council in the late 1960s (Molnar, 1997). Christianity, narrowly Catholic, introduced in Flores Island from 16th Century by the Portuguese colonialism in the eastern part of Flores, then slowly spread 17th Century when the Dutch invaded and overtook the island from Portuguese. By 1875, Christian missionaries continued by the Jesuits in the former Portuguese Catholic area. The Ngada region, the region where the Hoga Sara occupied, only accept Catholicism influence by 70's because in the early years the Dutch do not really interested either political or economically in that region (Molnar, 1997). Catholic missionaries placed a big commitment to 'inculturate' the Catholic teaching into the life of Hoga Sara, and this commitment shown by Paul Arndt SVD ethnographic works and linguistic studies on the culture of local traditions (Molnar, 1997).

One of the most remarkable inculturation components between the Catholic missionaries with the local culture of Hoga Sara is the employing of indigenous language in translating the Bible and liturgy (Molnar, 1997). Also, some traditional symbols that did not stand in direct contradiction to the doctrine utilized in the liturgy process. Catholic missionaries also tried to fit local religious categories, as an example the Creator Divinity into Christian scheme, by retained the local name for a God that the people used to previously, however, at certain degree, the other traditional belief categories especially the nature spirits, witches, and ancestral spirit relegated to Satan category (Molnar, 1997). High commitment to 'inculturate' into local culture spectrum, Catholic missionaries, in the meantime, seems very 'ethnocentric' towards the local traditional practice and ritual, Arndt (1955) for example stated "...it (traditional religion) does make them religious", and traditional ritual practices viewed very negatively by the church and often forbidden (Molnar, 1997).

Even with the slow spread of Catholicism, the missionaries could be considered as successful, with certain changes and adaptations of Christian values into the life of the Hoga Sara (Molnar, 1997). In daily life, the practice of crossing oneself before and after every meal, rosary-wearing, praying to the Virgin Mary and attending the Sunday mass service, became dominantly after the acceptance of Christian faith. In terms of cosmology and ritual practices, the introduction of Catholicism according to Molnar (1997) did not fundamentally change the concepts of Hog Sara cosmos that traditionally divided their cosmos into three; the sky, the physical plane of human habitation, and the invisible realm of the ancestors. Another advantage for Christian to succeed is the idea of the Trinity, where the concept of three really dominant in the practice of local Hoga Sara, therefore faith lying on Trinity become easily accepted and seen as more or less the same with local cosmological (Molnar, 1997).

Grenier \& Dauphin (2009) wrote 'Werner Jaegerhuber's Messe Sur Les Airs Vodouesques: The Inculturation of Vodou in a Catholic Mass' about the integration of Haitian Vodou melodies in a Catholic mass. The work was concerned with attempts by Jaegerhuber to promote the Vodou melodies in the Christian mass in Haiti. Unfortunately, his effort was facing difficulties since the Haiti's Catholic clergy has a little tolerance for the integration of Vodou melody into the Roman liturgy. This influenced 
much by assumptions that the practice of Vodou became the retarding factor in the advancement of Vodou community. Monseigneur Robert, the Bishop of Les Gonaives Cathedral of Haiti, at the early stage against the idea of integrating Vodou melodies into performance within Christian liturgy in the Church, his idea on Vodou tradition was "a bit God and a bit of the devil" (Robert, 1962, in Grenier \& Dauphin, 2009). However, Jaegerhuber viewed this issue from different perspective and he suggested that a rational bridge could be constructed and traversed from Catholicism to Vodou.

The inculturation of Vodou culture into Catholic Mass by Jaegenhuber marked with the integration of local Vodou melodies, and in the meantime, Jaegenhuber also took Georgian tradtion into consideration, in other words, he mined together both elements of specific melody, by referencing a characteristic texture, rhythm and conventional practice (Grenier \& Dauphin, 2009). The evidence of inculturation of Vodou elements into the 'Messe' displayed by Jaegenhuber in a manner that he intuits link between an aspect of the Vodou religion and a specific moment, textual or liturgical, in the roman liturgy and its Biblical sources (Grenier \& Dauphin, 2009).

In short, inculturation is crucial for Christian missionary in winning the heart of non-Christian to accept and convert into Christianity. While succeeding the Gospel goals, they blend themselves into local cultures and values and in the meantime spreading their teachings.

\section{METHODOLOGY}

The results discussed in this paper is part of the findings of my Bachelor Degree FYP entitled 'The Life of Christian Melanau in Sarawak: A Case Study of Kampung Bungan Besar, Matu' in 2015 and had been submitted to Universiti Malaysia Sarawak (UNIMAS). It was designed as qualitative research, the data collection employed are participant observation and interview.

Six weeks of fieldwork had been conducted in from January until February 2015 in the study area, Kampung Bungan Besar, Matu. Participant observation was done by participating with the Christian liturgies (see Table 1) and in the meantime maintaining the 'distance' as a researcher. Other than the information gathered through participation in these liturgies, information in terms of daily experience living with the community throughout the fieldwork course also counted in. The interview also conducted in collecting information from the field. An in-depth interview with open-ended interview questions was conducted with a few key informants comprises of priests ulo sebiang, Christian converts and a member of the church. The interview schedule prepared comprises of topics and sub-topics of research subjects as guidance while conducting the interviews.

Table 1

Liturgies attended by the researcher throughout the fieldwork course.

\begin{tabular}{lll}
\hline & Date of Liturgy & Theme \\
\hline 1. & January 11th, 2015 (Sunday) & The Baptism of the Lord \\
\hline 2. & January 18th, 2015 (Sunday) & 2nd Ordinary Sunday \\
\hline 3. & January 25th, 2015 (Sunday) & 3rd Ordinary Sunday \\
\hline 4. & February 1st, 2015 (Sunday) & 4th Ordinary Sunday \\
\hline 5. & February 7th, 2015 (Saturday) & 5th Ordinary Sunday \\
\hline 6. & February 8th, 2015 (Sunday) & 5th Ordinary Sunday \\
\hline 7. & February 15th, 2015 (Sunday) & 6th Ordinary Sunday \\
\hline 8. & February 18th, 2015 (Wednesday) & Ash Wednesday \\
\hline
\end{tabular}




\section{Location of Melanau Settlements on Coast of Sarawak.}

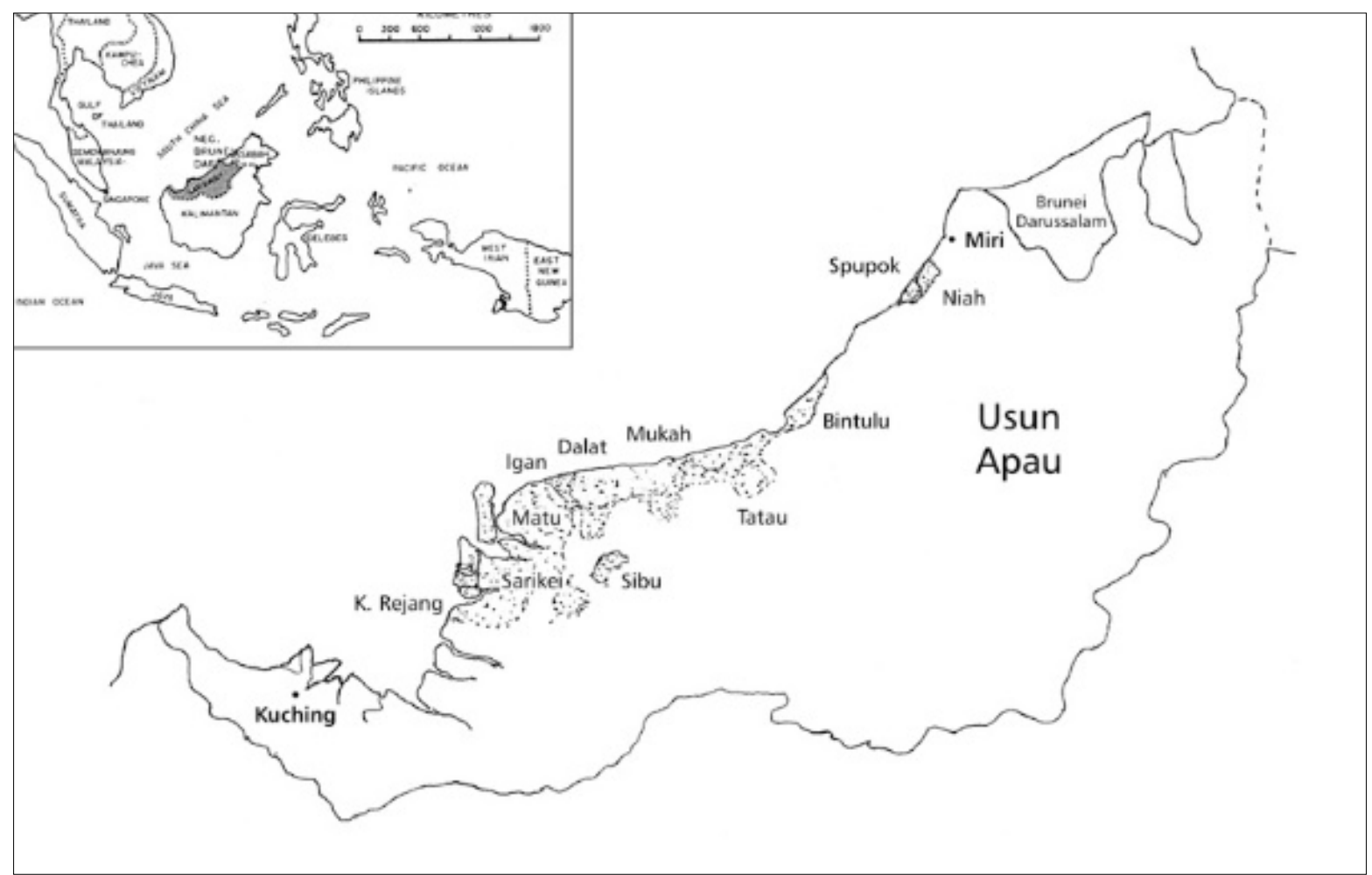

Figure 1. The location of Melanau settlements in Sarawak (Beavitt, 2007). Study area located somewhere in Matu Division.

\section{RESULT AND DISCUSSION}

Roman Catholic Christianity was a success among the Melanau of Kampung Bungan Besar, Matu. Based on my observation, Christian is the main religion of the villagers nowadays, as majority of them was converted to Christianity while the younger generation that was born as Christian had to follow the religion of their parents. Small fragments of villagers remain practicing adet dana and a notable increase in the number of Muslim converts following mixed marriage.

The triumph of Roman Catholic missionaries over the traditional adat belief Melanau in Kampung Bungan Besar, Matu, has to do with to the process of 'inculturation'. A large number of conversions into Christians indicate that this foreign religion is widely accepted among the villagers. Missionary successes are rooting from the strategies being employed in spreading the gospel message and teachings through inculturation into the daily life of the Melanau in the study area.

\section{Object-centered Inculturation}

Chua (2012, p. 143) stated that the Christianity 'inculturation' within the local context of Borneo cultures are tied with inculturation that is 'object-centered' and 'aesthetic.' By 'object-centered' and 'aesthetic' inculturation referring to the adoption of local culture both materially and ideally, and later integrated into Christianity liturgy. This was symbolic of local culture manifestation. The common scenarios are also my finding on the 'inculturation' of Roman Catholic Christianity with the local spectrum of Melanau culture in Kampung Bungan Besar, Matu.

In Kampung Bungan Besar, Matu, I observed the similar pattern of 'object-centered inculturation.' In every liturgies occasion that I attended, I noticed that the priest or ulo sebiang is wearing the traditional costume 'Bajo' Melanau. Other than ulo sebiang, the Bible text readers for the liturgy, the master of ceremony, and the wardens of the chapel also wearing the traditional costume 
during the service. I myself was directly participated in the liturgy where I appointed to become First Bible Reader in two separate masses; January 25th, 2015 Sunday Masses: 3rd Ordinary Sunday Time and February 1st, 2015 Sunday Masses: 4th Ordinary Sunday Time. In performing my duties during these masses, I was told to wear the Melanau costume. The examples of Melanau costume-wearing in Christian Liturgy masses can be seen in the Figure 2 and Figure 3 below.

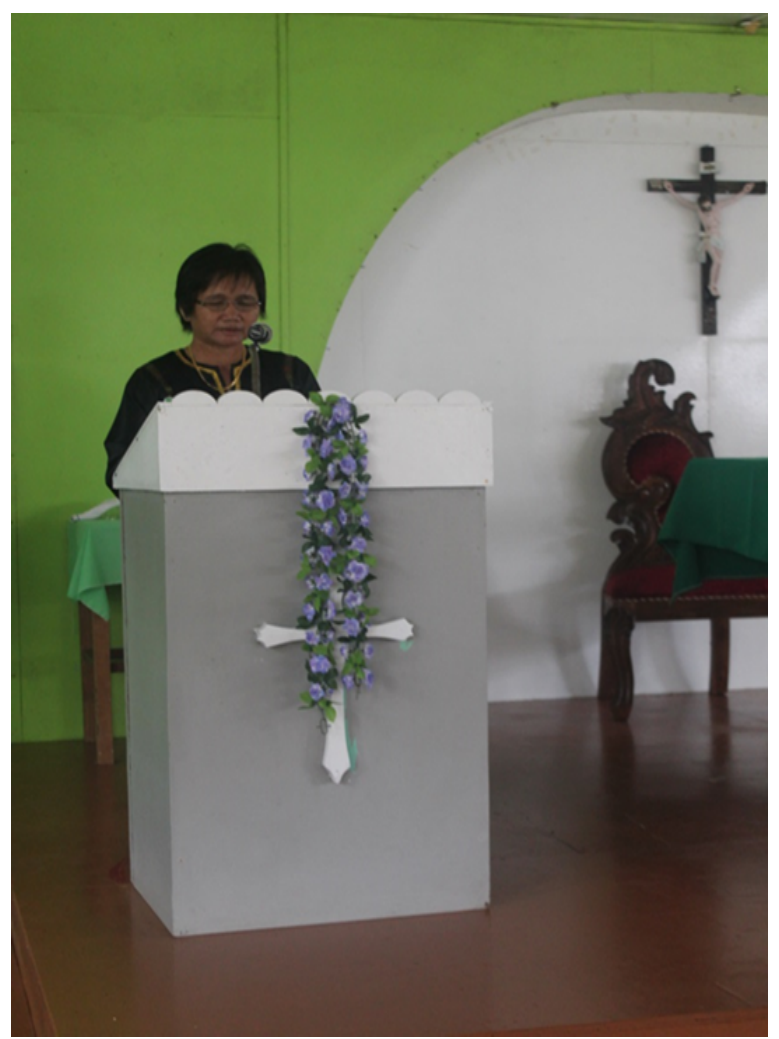

Figure 2. The priest 'ulo sebiang' conducting the mass in traditional Melanau costume.

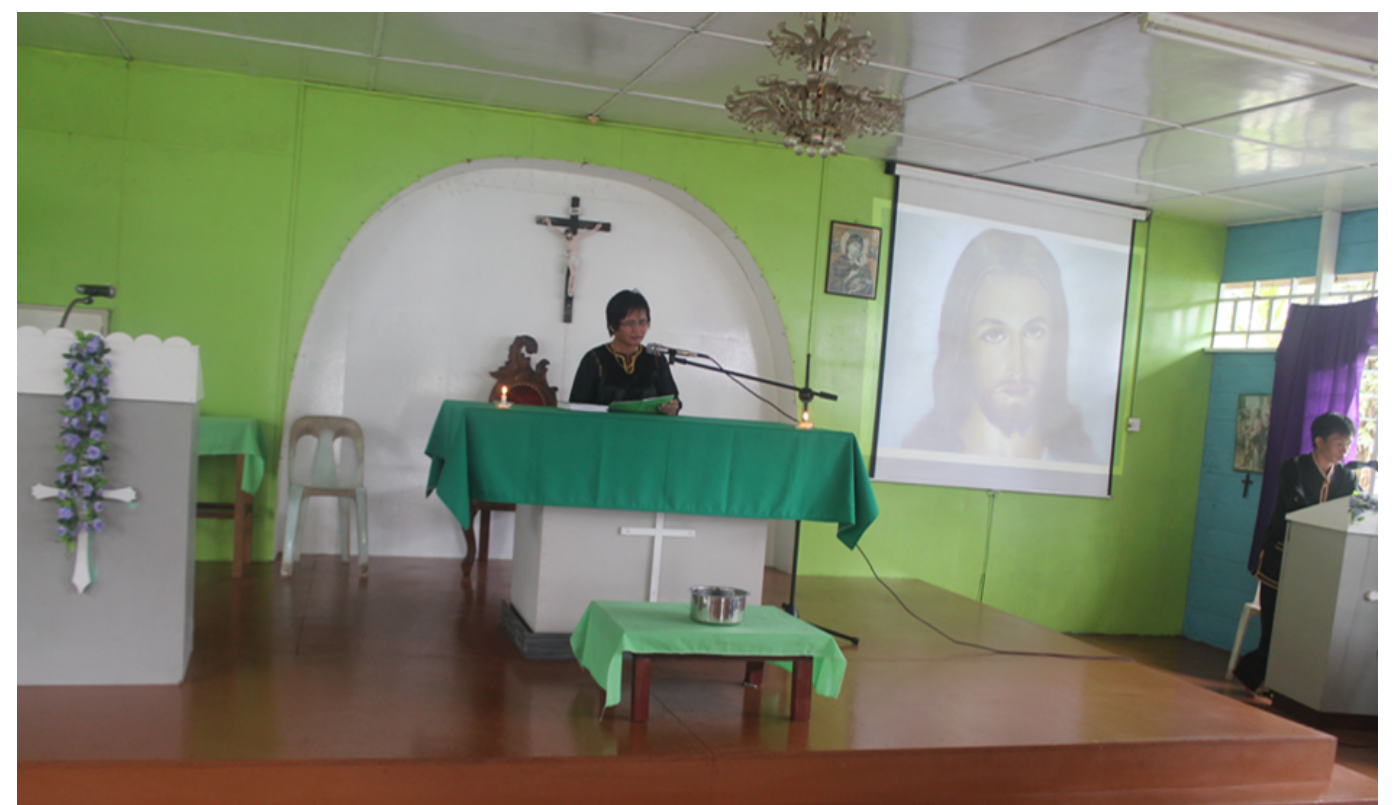

Figure 3. Other than the priest (center) the M.C. (Right in the figure) and Bible Reader also wears traditional costume.

My informants echoed out that the wearing of Melanau-traditional costume in the liturgy is the significance of the integration of Melanau 'culture' into Christianity. While the value of Christianity is 
being actively spread among villagers, the local Melanau culture is not a subject to be abandoned. Therefore, one way of retaining it is through the integration of the traditional value into the mainstream belief and practice of Christian religion and liturgy. Another rationale of wearing the traditional costume is to ensure appropriate dress code during service to the God and Church.

Other than the wearing of traditional Melanau costume, another form 'object-centered inculturation' observed is the use of Melanau 'small rice basket' (see Figure 3 \& Figure 4) during the masses. This 'small rice basket' or in Melanau terms baken umit is made up of rattan and sago plank. It is traditionally used to clean the rice prior to cooking. It has now been integrated into the liturgy and used in the offertory during the mass. The donation collected during the mass will be placed into this baken and a warden will bring it to the altar as an offertory. Again, this signifies the integration of Melanau material culture into Christian liturgy.

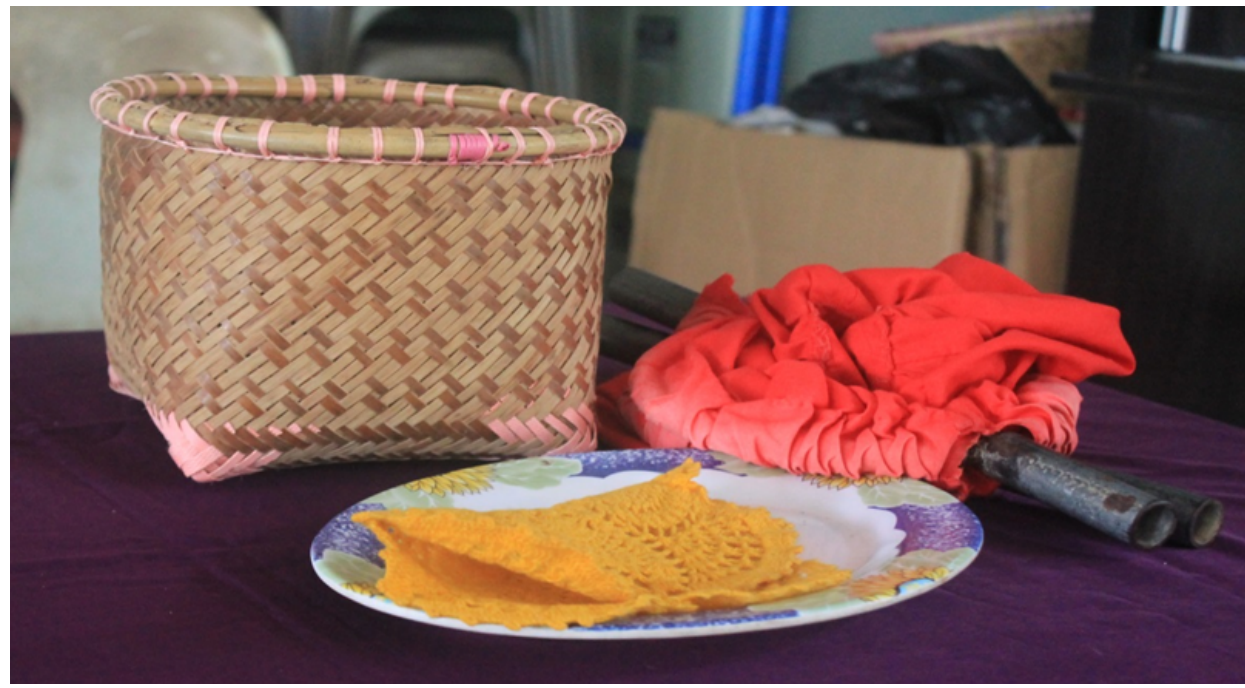

Figure 4. The 'baken' that used in the offertory during the mass. The red cloth will be used to collect donation from the attendees and later the donations will be placed in the 'baken' and send to the altar.

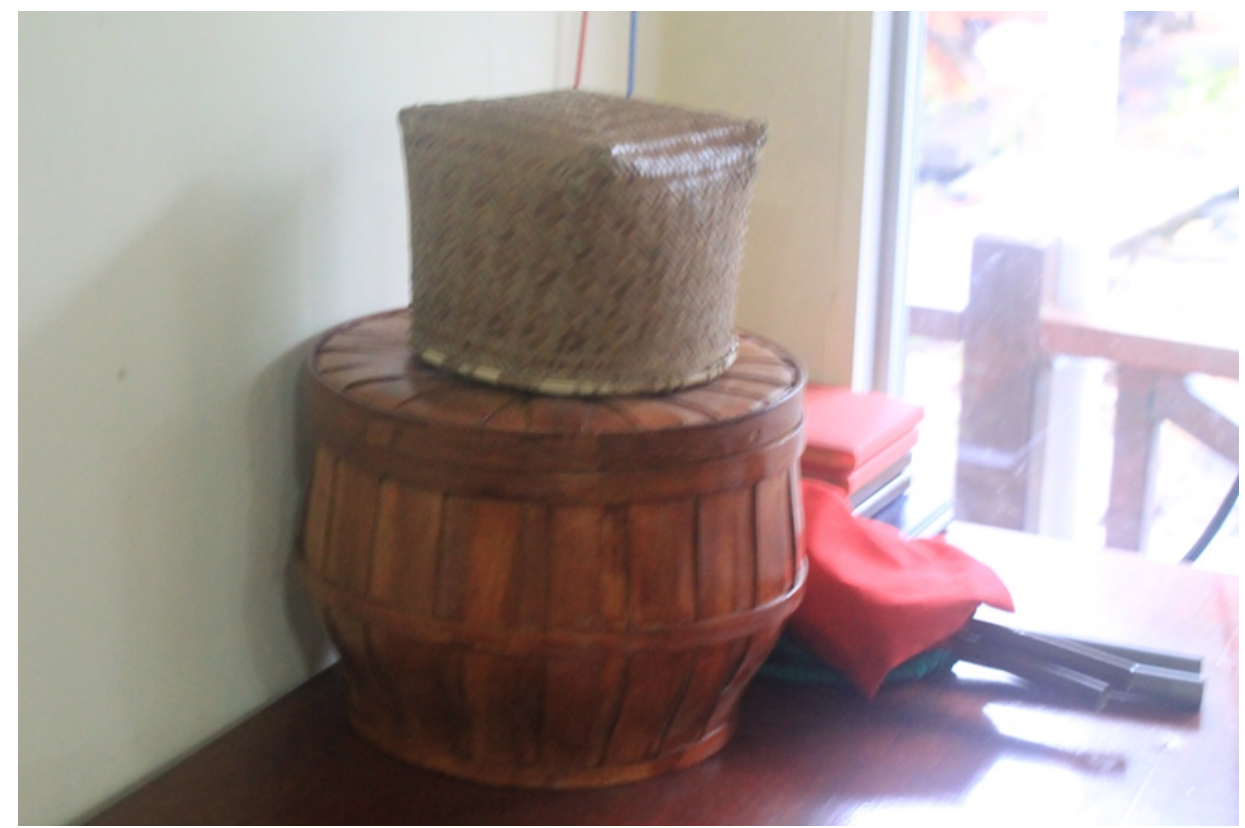

Figure 5. Another picture of baken (top). 


\section{Liturgical Inculturation}

Another degree of inculturation that I noticed among the Roman Catholic Christian and the local culture of Melanau is what Chupungo (1992) termed as 'liturgical inculturation.' 'Liturgical inculturation' refers to "a process of inserting the texts and rites of the liturgy into the framework of the local culture" such that they would "assimilate people's thought, language, value, ritual, symbolic and artistic pattern" (Chupungo, 1992, in Chua, 2012, p. 142).

In the context of Christian Melanau in Kampung Bungan Besar, Matu, the most notable forms of 'liturgical inculturation' presence in terms of language, where the local Melanau language being used interchangeably with the Malay language in the Christian liturgies. In the liturgical process, for example, the Melanau language used alongside with the Malay language, since Bible used is Indonesian-translated. This is similar to Molnar's (1997) that the church translating the gospel message into the local language in order to ease the delivery of the message and the words of the Bible. Based on my observation in the liturgies that I attended, the main language used is Malay, with main prayers are recite proudly in Melanau, such as the graces of 'Our Father' and 'Hail Mary'. The grace- of 'Our Father' in English version is as follows:

Our Father, who art in heaven

Hallowed by Thy Name,

Thy kingdom come,

Thy will be done,

On earth as it is in heaven.

Give us this day our daily bread, and forgive us our trespasses,

as we forgive those who trespass against us;

and lead us not into temptation,

but deliver us from the devil. Amen.

(Source: Catholic Planet (n.d.))

The 'Our Father' in Melanau version (direct translation from English) is Tama Kamei and the prayer is as follows:

Tama Kamei, a bei dagen sorga,

Tebilangan ngadan Kaau,

Labe' peritah Kaau,

Badak nyadin wa' tekah Kaau,

Bau tana' alah tan dagen sorga.

Juh gak kamei lau ih,

Wa' ba'kanen kamei jelau-jelau,

Maap kamei dusa kamei,

Alah tan kamei kemaap a bedusa ga' kamei,

Kak meririn kamei mapun suba' iblis,

Tapi lepeh kamei kuman wa; ja'et. Amen.

Hail Mary in English version and the Melanau version in italic:

Hail Mary, full of grace.

Our Lord is with Thee.

Blessed art thou among women

and blessed is the fruit of thy womb,

Jesus.

Holy Mary, Mother of God, pray for us sinners,

now and at the hour of our death. 
Amen.

(Source: Catholic Planet (n.d.))

Puji Maria, peno' bahada,

Allah Ta'ala jegem Kaau,

Berket Kaau kuman semuah amero,

serta berket Anik Kaau Jesus.

Elkadisa Maria, Tina Allah Ta'ala,

Sebiang gim kamei a' bedusa,

Ajau ih serta lian kamei ba' matai.

Amen.

English version of 'The Apostle Creed', a prayer of Faith in the teaching of Jesus and his church:

I believe in God,

the Father Almighty,

Creator of Heaven and earth.

I believe in Jesus Christ, His only Son, our Lord,

who was conceived by the Holy Spirit, born of the Virgin Mary,

suffered under Pontius Pilate,

was crucified, died and was buried, He descended to the dead.

On the third day, He rose again.

He ascended to Heaven and is seated at the right hand of the father.

He will come again to judge the living and the dead.

I believe in the Holy Spirit,

the Holy Catholic Church, the communion of saints,

the forgiveness of sins, the resurrection of the body,

and life everlasting. Amen.

(Source: Catholic Planet (n.d.))

The title of Melanau version of 'The Apostle Creed' was slightly modified and locally known as Ako' Pesaya, which literally means 'I believe.' Similarly, like the other prayers, the verses are directly translated from the English version, meanwhile Melanau version is as follow:

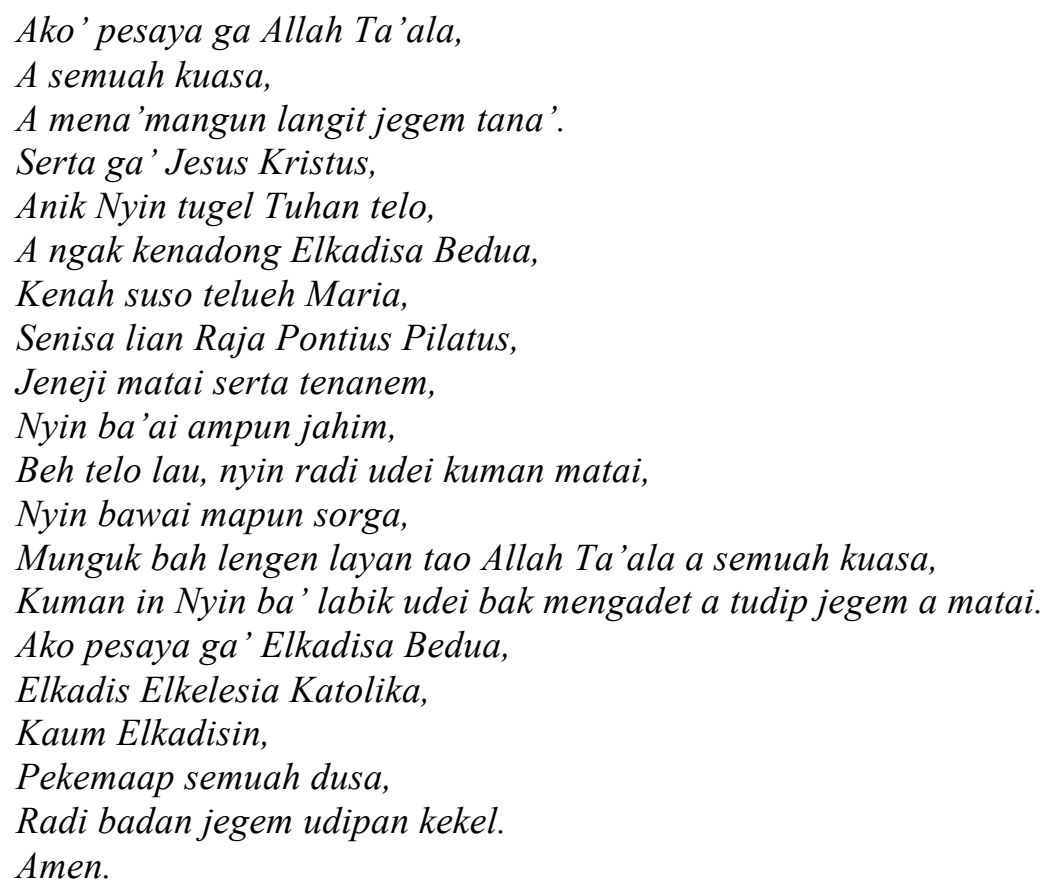


These three prayers are the major and the most commonly used in the Christian liturgies. One of my informants, Marcos Musang, is the guitarist for the Christian liturgy of St Victoria Chapel, stated that in the past there were a lot of songs 'lagu sebiang' in Melanau language. Unfortunately, most of the songs have been forgotten since only the older generation know how to sing it. On the other hands, the younger generation of Christian, prefers the contemporary prayer songs in Malay and English which are also widely used by Christians in other part of the country. Marcos Musang, a Christian by conversion, on the thought of the usage of local language found that is helpful in a way and provide a better understanding of the teaching and religion itself the local group since in that time the level of literacy among the villagers is still low.

Christian missionary in Kampung Bungan Besar, Matu is based from St Bernard Church, Dalat, a Melanau populated area, and therefore it is an advantage for the missionary to easily penetrate into the setting of Melanau in the village. Plus, the missionary team also incorporated local priests that speak the similar languages of targeted group to ease the missionary works. In the matter of fact, most of the foreign priests that involve in the missionary effort in Melanau-populated area, can converse in Melanau fluently. The number of Malay and English literate in the past is low; therefore, to use Malay and English languages in the mission works will not be fruitful and the villagers will not understand them. Through this inculturation the teachings can be spread faster and penetrate into society context. Therefore, it can be concluded that use of local Melanau language is the key to the success of Christian missionary in Kampung Bungan Besar, Matu.

\section{CONCLUSION}

In short, the inculturation process took place in the context of Christian and local culture of Melanau in Kampung Bungan Besar, Matu, was 'object-centered and esthetical' and 'liturgical.' Both processes play significant roles in ensuring the success of the missionaries. The Christian mission first blends themselves into local cultures to ensure their teaching understandable and acceptable to the locals, and, in the same time, to win the heart of the locals to accept Christianity in their daily life. Inculturation is a crucial element for missionary to succeed in the non-Christian setting.

\section{ACKNOWLEDGEMENTS}

This paper is the sub-topic of my Final Year Project (FYP) under the supervision of Dr. Elena Chai, it is therefore, I would like to give special thanks to her for the guidance and supervision. Besides, I am indebted to the villagers of Kampung Bungan Besar, Matu for the cooperation during the fieldwork course. 


\section{REFERENCES}

Arndt, P. (1955). The Country and the people of Flores. Mission Bulletin 7, 591-193.

Aseng, C. T. (1998). History and relationship of Melanau to other ethnic groups. In A. Wing (Ed.). Sejarah, Budaya dan Realiti Baru Kaum Melanau (pp. 1-19). Kuching: Lembaga Amanah Kebajikan Kaum Melanau Sarawak.

Beavitt, P. (2007). Melanau Sickness Images: Spirit Given Physical Form. Interfaces 26, 95- 102.

Catholic Planet (n.d.). Retrieved March 25 ${ }^{\text {th }}, 2015$ from www.catholicplanet.com/.

Chua, L. (2012). The Christianity of Culture. New York, US: Palgrave Macmillan.

Chupungo, A. J. (1992). Liturgical inculturation: Sacramentals, Religiosity and Catechesis. Collegeville, MN: Liturgical Press.

Dzulfawati Haji Hassan. (2006). Upacara kematian Melanau Likow di Sarawak. Kota Samarahan: Universiti Malaysia Sarawak.

Grenier, R. \& Dauphin, C. (2009). Messe sur les airs vodousques: The Inculturation of Vodou in a Catholic Mass. Black Music Research Journal, 29 (1), 51-82.

Ismail Abdul Rahman. (2000). Gerakan Gereja Katolik di Malaysia. Bangi: Penerbit Universiti Kebangsaan Malaysia.

Jeniri Amir (1998). Adat resam kaum Melanau. In A. Wing (Ed.), Sejarah, Budaya dan Realiti Baru Kaum Melanau (pp. 32-50). Kuching: Lembaga Amanah Kebajikan Kaum Melanau Sarawak.

John Paul II, P. (1990). "Redemptoris in Missio: On the permanent Validity of the Church's Missionary Mandate. Retrieved November 11th, 2009 from http://www.vatican.va/holyfatherjohn_paul_ii/encyclicals/documents/hf_jp_ii_enc_07 121990 redemtoris-missio en.html.

Molnar, K. (1997). Christianity and Traditional Religion among the Hoga Sara of West-Central Flores. Anthropos, Bd. 92, H 4./6, 393-408.

Ooi, K. G. (1991). Mission Education in Sarawak during the Period of Brooke Rule 1840-1946. Sarawak Museum Journal 42 (63), 282-373.

Robert, B. J. M. (1962). Haitian bishop on Voodoo. The Tablet: A Weekly Newspaper and Review 216 (3934), 1206-1207.

Stewart, C. (1999). Syncretism and its synonyms: Reflections on cultural mixture. Diacritis 29 (3), 40-62. 